Article

\title{
Prediction of Lithium-ion Battery Thermal Runaway Propagation for Large Scale Applications Fire Hazard Quantification
}

\author{
Mohamad Syazarudin Md Said (D) and Mohd Zahirasri Mohd Tohir * (D) \\ Safety Engineering Interest Group, Department of Chemical and Environmental Engineering, \\ Faculty of Engineering, Universiti Putra Malaysia, 43400 Serdang, Selangor Darul Ehsan, Malaysia; \\ syazarudin@upm.edu.my \\ * Correspondence: zahirasri@upm.edu.my
}

Received: 19 July 2019; Accepted: 26 August 2019; Published: 5 October 2019

\begin{abstract}
The high capacity and voltage properties demonstrated by lithium-ion batteries render them as the preferred energy carrier in portable electronic devices. The application of the lithium-ion batteries which previously circulating and contained around small-scale electronics is now expanding into large scale emerging markets such as electromobility and stationary energy storage. Therefore, the understanding of the risk involved is imperative. Thermal runaway is the most common failure mode of lithium-ion battery which may lead to safety incidents. Transport process of immense amounts of heat released during thermal runaway of lithium-ion battery to neighboring batteries in a module can lead to cascade failure of the whole energy storage system. In this work, a model is developed to predict the propagation of lithium-ion battery in a module for large scale applications. For this purpose, kinetic of material thermal decomposition is combined with heat transfer modelling. The simulation is built based on chemical kinetics at component level of a singular cell and energy balance that accounts for conductive and convective heat transfer.
\end{abstract}

Keywords: thermal runaway propagation; lithium-ion battery; cascade failure; fire and explosion

\section{Introduction}

The applications of lithium-ion batteries (LIB) have been proliferating from small handheld devices to large-capacity high-voltage applications. According to a projection by Bloomberg, the demand is expected to increase in the near future. With the gradual global phasing out of internal combustion engines, the highest demand will come from the automotive sector due to the electrification of passenger vehicles [1,2]. A range of lithium-ion battery chemistries is available. Some of the technology has been successfully upscaled for electrified vehicles as compiled by Lu et al. in [3]. According to a report published by Bloomberg, lithium cobalt oxide chemistry is the most favorable chemistry at the moment, accounting to $39 \%$ of total batteries in the automotive sector [4].

Lithium-ion batteries are constructed in a unique way where both fuel (anode) and oxidiser (cathode) are placed together in a sealed container [5]. The fire safety concern of LIB stems from its components where a combination of highly reactive electrodes and flammable organic electrolytes is present. The inclusion of ignition from any sources such as short-circuit or external heating would complete the fire triangle and consequently leads to fire incident. In addition, there is an immense amount of energy stored within the small device. Most of the disastrous incidents related to LIB are caused by thermal runaway, which has been reported to be the common failure mode. This situation raises the interest in understanding the underlying causes and exploring the prospective techniques to alleviate the problem [6]. 
Thermal runaway is triggered by abusive environments such as charging and discharging beyond the specified limit, exposure to high temperature, failure of thermal management and subjection to physical impact, which potentially entails induced internal short-circuit [7]. The heat generated from the operation of LIB outside the stability window will induce the heat-activated exothermic reactions inside the battery, which in turn will generate a high amount of heat. The increase in temperature due to exothermic reactions accelerates the reaction kinetics and leads to further temperature rise [8]. In some reactions, the heat is released alongside the emission of flammable and toxic gases.

Abuse tolerance is a daunting technical barrier for LIB as it is related to safety issues. Upon which, mechanically, electrically or thermally, the battery exhibits anomalous temperature hike, which could potentially lead to disastrous shatter of the battery structure [9]. Venting of potentially flammable gases is an expected phenomenon during thermal runaway. The safety venting is an engineered safety mechanism to prevent internal pressure build up inside the battery and consequently leads to catastrophic rupture of the cell casing [10]. Additional energy from overcharge activity and external heating exposure is expected to aggravate the severity of thermal runaway consequences [11].

The intrinsic hazard of lithium-ion battery has been well identified that the battery system is usually equipped with multilayer safety mechanism for hazard mitigation and accident prevention purposes [12]. Satisfactory abuse tolerances can be achieved by disposing a substantial amount and typically redundant safety devices [13]. Despite the multi-layer safety mechanisms, in addition to the improved inherent safety characteristic of batteries, undesirable incidents are still inevitable. This situation raises the concern about the safety of this widely available electrochemical energy storage system.

The apprehension of the hazards involved hinders the use of LIBs in applications with zero tolerance for a catastrophic failure. Due to this reason, a numerical indicator of the associated hazard is imperative to provide baseline for understanding the hazards involved and the subsequent safety assessment. In conducting quantified risk assessment (QRA), the information pertaining probability and consequence of the hazard is necessary. The odds of the incidents are established from statistical data and the consequence is the numerical indicator acquired from experimental evaluation or numerical modelling. The output from the quantitative risk assessment can be utilized to establish potential fire and explosion scenarios related to battery for the subsequent emergency response and hazard mitigation. Additionally, the output can provide an objective quantification of risk which could lead to an optimization of the selection of suitable design for a vehicle in a cost-effective manner. The emerging interest in using a risk-based approach for many other applications pertaining to vehicle fire safety may also benefit from the quantitative risk assessment study.

While being able to provide useful insight on the thermal hazard of lithium-ion battery, experimental techniques are capital-intensive with limited applicability beyond the tested conditions. Calorimetry technique has been used to study thermal decomposition and reactivity of battery components and complete battery assembly with multiple references are reported in the literature. Some of the prevalence methods are Differential Scanning Calorimetry (DSC) [14-18], Thermogravimetry Analysis (TGA) [17,19], Accelerating Rate Calorimetry (ARC) [15,20-23] and VSP2 Adiabatic Calorimeter [24-29]. The kinetics of decomposition reaction of lithium-ion battery active materials can be described by Arrhenius equation and can be further utilized for simulation of thermal runaway of a practical lithium-ion battery [13,30-33].

At the moment, most of the works reported in the literature related to thermal runaway study of lithium-ion batteries have been concentrated on the impacts and failure consequences of a single cell. There are limited studies conducted to quantify thermal runaway hazards of lithium-ion batteries beyond singular cell level. The application of the lithium-ion batteries which previously circulating and contained around small scale electronics is now expanding into emerging markets such as electromobility and stationary energy storage. This situation necessitates for the understanding of the hazard involves in a large scale. It is the aim of this work to develop a numerical model to predict propagation of thermal runaway from a single suffering cell into the whole battery module. 
The initiation of thermal runaway considered is short-circuit induced by physical impact. For this purpose, thermal decomposition kinetics of battery fundamental components are combined with conductive and convective heat transfer modelling.

\section{Numerical Modelling of Lithium-Ion Battery Thermal Runaway Propagation}

In large-scale applications such as automotive sector, the capacity provided by one single cell is not sufficient to satisfy the high energy and power demand. Therefore, it is necessary to build battery packs with a big amount of single cells packed and connected together. A module is assembled by electrically connecting a number of individual cells by either series or parallel or combination of both. The specifications of the battery for this study are presented in Table 1. Thermal properties of the cell canister and volumetric mass of the battery components as collected from literature are presented in Table 2.

Table 1. Cell specifications.

\begin{tabular}{cc}
\hline Specification & Value \\
\hline Form Factor & Cylindrical 18,650 \\
Diameter (mm) & 18 \\
Length (mm) & 65 \\
Nominal voltage (V) & 3.7 \\
Maximum voltage (V) & 4.2 \\
Minimum voltage (V) & 2.8 \\
Chemistry & Lithium cobalt oxide cathode \\
& Graphite anode \\
\hline
\end{tabular}

Table 2. Battery physical parameters for thermal runaway modelling.

\begin{tabular}{ccc}
\hline Property & Value & Reference \\
\hline Specific heat capacity, $\mathrm{C}_{\mathrm{p}}(\mathrm{J} / \mathrm{kg} . \mathrm{K})$ & 830 & {$[30]$} \\
Volumetric mass of cathode $\left(\mathrm{kg} / \mathrm{m}^{3}\right)$ & $1.221 \times 10^{3}$ & {$[13]$} \\
Volumetric mass of anode $\left(\mathrm{kg} / \mathrm{m}^{3}\right)$ & $6.104 \times 10^{2}$ & {$[13]$} \\
Volumetric mass of electrolyte $\left(\mathrm{kg} / \mathrm{m}^{3}\right)$ & $4.069 \times 10^{2}$ & {$[13]$} \\
Thermal emissivity, $\varepsilon$ & 0.8 & {$[30]$} \\
\hline
\end{tabular}

The immense amount of heat released during thermal runaway originates from local thermal decomposition reactions of the battery fundamental components. In this work, there are four decomposition reactions considered for the purpose of thermal runaway simulation. There are two reactions at anode, which are the breakdown of solid electrolyte interphase (SEI), and anode-electrolyte reaction. Meanwhile, both cathode and electrolyte have one reaction. Each of the reaction possesses characteristic decomposition reaction model and parameters. The thermal decomposition kinetics of the battery components for thermal runaway modelling which are collected from literature are listed in Table 3.

Table 3. Kinetic parameters of thermal decomposition reaction of lithium-ion battery fundamental components. The work is focused on lithium-ion battery with lithium cobalt oxide cathode and carbon anode.

\begin{tabular}{ccccc}
\hline Components & Reaction Enthalpy (J/g) & Activation Energy (J/mol) & Frequency Factor (1/s) & References \\
\hline Solid Electrolyte Interphase & 257 & $1.3508 \times 10^{5}$ & $1.667 \times 10^{15}$ & {$[34]$} \\
Anode & 1714 & $1.3508 \times 10^{5}$ & $2.5 \times 10^{13}$ & {$[34]$} \\
Cathode & 314 & $1.1495 \times 10^{5}$ & $1.75 \times 10^{9}$ & {$[35]$} \\
Electrolyte & 155 & $1.7 \times 10^{5}$ & $2.5 \times 10^{13}$ & {$[13]$} \\
\hline
\end{tabular}




\subsection{Energy Balance of a Single Battery}

In a lumped thermal model, the rate of temperature change in the battery can be expressed as in Equation (1).

$$
\frac{\mathrm{dT}(\mathrm{t})}{\mathrm{dt}}=\frac{\mathrm{Q}(\mathrm{t})}{\mathrm{MC}_{\mathrm{p}}}
$$

where $\mathrm{T}(\mathrm{K})$ is the battery temperature, $\mathrm{t}(\mathrm{s})$ is the time, $\mathrm{Q}(\mathrm{W})$ is the net rate of heat generation, $\mathrm{M}(\mathrm{kg})$ is the mass and $C_{p}(\mathrm{~J} / \mathrm{kg} . \mathrm{K})$ is the battery specific heat capacity.

The rate of battery temperature change is directly proportional to the battery internal heat accumulation, which is a balance between self-generated and dissipated heat.

The net rate of heat generation is expressed in Equation (2), where $Q_{g e n}$ is the rate of internal heat generation and $Q_{\text {dissipation }}$ is the rate of heat transferred from battery to the surrounding.

$$
\mathrm{Q}(\mathrm{t})=\mathrm{Q}_{\text {gen }}(\mathrm{t})-\mathrm{Q}_{\text {dissipation }}(\mathrm{t})
$$

The $Q_{\text {dissipation }}$ term in Equation (2) is the rate of heat dissipation to the environment due to the convective and radiative heat transfer, as presented in Equation (3). The simulation work is focused on small cylindrical lithium-ion battery with $18 \mathrm{~mm}$ diameter and $65 \mathrm{~mm}$ height. To simplify the calculation process, it is assumed that the battery temperature is uniform throughout the whole structure and any temperature gradient is neglected. The small Biot number of 0.0179 as reported by Hatchard et al. in [30] warrants the use of lumped thermal model. Hence, there is no heat accumulation inside the battery components since it is assumed that the whole battery has a homogeneous temperature. Also, dissipation of heat from battery occurs by convection and radiation through battery surface. The rate of heat dissipation can be calculated using Equation (3).

$$
\mathrm{Q}_{\text {dissipation }}(\mathrm{t})=\mathrm{Q}_{\text {radiative }}(\mathrm{t})+\mathrm{Q}_{\text {convective }}(\mathrm{t})
$$

The rate of convective heat transfer is given in Equation (4).

$$
\mathrm{Q}_{\text {convective }}(\mathrm{t})=\mathrm{h} \mathrm{A}\left(\mathrm{T}(\mathrm{t})-\mathrm{T}_{\mathrm{amb}}(\mathrm{t})\right)
$$

where $h\left(W / m^{2} . K\right)$ is the heat transfer coefficient, $A\left(\mathrm{~m}^{2}\right)$ is the surface area for heat exchange, $T(K)$ is the instantaneous battery temperature, $t(s)$ is the time, and $T_{a m b}(K)$ is the ambient temperature.

The rate of radiative heat transfer is given in Equation (5).

$$
\mathrm{Q}_{\text {radiative }}(\mathrm{t})=\varepsilon \sigma \mathrm{A}\left(\mathrm{T}(\mathrm{t})^{4}-\mathrm{T}_{\mathrm{amb}}(\mathrm{t})^{4}\right)
$$

where $\varepsilon$ is the battery surface emissivity, $\sigma\left(\mathrm{W} / \mathrm{m}^{2} \mathrm{~K}^{4}\right)$ is the Stefan-Boltzmann constant, $\mathrm{A}\left(\mathrm{m}^{2}\right)$ is the surface area for heat exchange, $\mathrm{T}(\mathrm{K})$ is the instantaneous battery temperature and $\mathrm{T}_{\mathrm{amb}}(\mathrm{K})$ is the ambient temperature.

The rate of internal heat generation is expressed in Equation (6), which is a sum of rate of heat generation from chemical reactions, $\mathrm{Q}_{\mathrm{cr}}$ and short-circuit, $\mathrm{Q}_{\mathrm{sc}}$.

$$
\mathrm{Q}_{\text {gen }}(\mathrm{t})=\mathrm{Q}_{\mathrm{cr}}(\mathrm{t})+\mathrm{Q}_{\mathrm{sc}}(\mathrm{t})
$$

$\mathrm{Q}_{\mathrm{sc}}$ in Equation (6) is the rate of heat generation from short-circuit and can be expressed as in Equation (7) [36].

$$
\mathrm{Q}_{\mathrm{sc}}(\mathrm{t})=\frac{1}{\Delta \mathrm{t}}\left[\Delta \mathrm{H}_{\mathrm{sc}}-\int_{0}^{\mathrm{t}} \mathrm{Q}_{\mathrm{sc}}(\tau) \mathrm{d} \tau\right]
$$

where $\Delta t(\mathrm{~s})$ is the duration of short-circuit, $\Delta \mathrm{H}_{\mathrm{sc}}(\mathrm{J})$ is the amount of electrical energy discharged into heat during short-circuit, $\mathrm{t}(\mathrm{s})$ is the instantaneous time and $\tau(\mathrm{s})$ is the time at the point of short-circuit. 
The amount of heat generated from rapid discharge of electrical energy during short-circuit can be calculated using Equation (8) [36].

$$
\Delta \mathrm{H}_{\mathrm{sc}}=\mathrm{CV}
$$

where $\mathrm{C}(\mathrm{Ah})$ is the battery capacity and $\mathrm{V}(\mathrm{V})$ is the battery voltage.

$\mathrm{Q}_{\mathrm{cr}}$ in Equation (6) is the total rate of heat generation from chemical reactions instigated by thermal instability of the battery components as expressed in Equation (9).

$$
\mathrm{Q}_{\mathrm{cr}}=\mathrm{Q}_{\mathrm{SEI}}+\mathrm{Q}_{\text {anode }}+\mathrm{Q}_{\text {electrolyte }}+\mathrm{Q}_{\text {cathode }}
$$

The rate of heat generation by each chemical reaction is proportionate to the rate of reactant consumption. In general, the rate of heat generation from the exothermic reactions can be expressed as in Equation (10).

$$
\mathrm{Q}_{\mathrm{x}}(\mathrm{t})=\Delta \mathrm{H}_{\mathrm{x}} \mathrm{W}_{\mathrm{x}} \frac{\mathrm{dc}_{\mathrm{x}}(\mathrm{t})}{\mathrm{dt}}
$$

where $\Delta \mathrm{H}_{\mathrm{x}}(\mathrm{J} / \mathrm{kg})$ is the reaction enthalpy, $\mathrm{W}_{\mathrm{x}}(\mathrm{kg})$ is the mass of the reactant and $\mathrm{c}_{\mathrm{x}}$ is the normalized reactant concentration.

\subsection{Modelling of Thermal Decomposition Kinetics}

\subsubsection{Solid Electrolyte Interface (SEI) Breakdown}

As described by Richard and Dahn [15], the reaction is first-order and the rate constant of this reaction can be expressed as in Equation (11).

$$
\mathrm{R}_{\mathrm{SEI}}=\mathrm{A}_{\mathrm{SEI}} \exp \left[-\frac{\mathrm{E}_{\mathrm{SEI}}}{\mathrm{RT}}\right] \mathrm{C}_{\mathrm{SEI}} \mathrm{m}_{\mathrm{SEI}}
$$

The rate of change in reacting species content during the reaction is presented in Equation (12).

$$
\frac{\mathrm{dc}_{\mathrm{SEI}}}{\mathrm{dt}}=-\mathrm{R}_{\mathrm{SEI}}
$$

The rate of heat evolution from the reaction can be calculated using Equation (13).

$$
\mathrm{Q}_{\mathrm{SEI}}=\Delta \mathrm{H}_{\mathrm{SEI}} \mathrm{W}_{\text {anode }} \mathrm{R}_{\mathrm{SEI}}
$$

where $\mathrm{R}_{\mathrm{SEI}}\left(\mathrm{s}^{-1}\right)$ is the rate constant of SEI decomposition reaction, $\Delta \mathrm{H}_{\mathrm{SEI}}(\mathrm{J} / \mathrm{kg})$ is the reaction enthalpy, $\mathrm{A}_{\mathrm{SEI}}\left(\mathrm{s}^{-1}\right)$ and $\mathrm{E}_{\mathrm{SEI}}(\mathrm{J} / \mathrm{mol})$ are frequency factor and activation energy respectively, $\mathrm{R}(\mathrm{J} / \mathrm{K} \cdot \mathrm{mol})$ is the gas constant, $\mathrm{T}(\mathrm{K})$ is the battery temperature, $\mathrm{m}_{\mathrm{SEI}}$ is the reaction order, $\mathrm{W}_{\text {anode }}(\mathrm{kg})$ is the mass of carbon in anode, and CSEI is the dimensionless amount of lithium-containing meta-stable species in the SEI.

\subsubsection{Reaction between Anode and Solvent}

The reaction between the solvent and the intercalated lithium within the anode will eventually form a secondary SEI layer. As described by Richard and Dahn [34], the reaction is first-order and the rate constant of this reaction can be expressed as in Equation (14).

$$
\mathrm{R}_{\text {anode }}=\mathrm{A}_{\text {anode }} \exp \left[-\frac{\mathrm{E}_{\text {anode }}}{\mathrm{RT}}\right] \exp \left[-\frac{\mathrm{z}}{\mathrm{z}_{0}}\right] \mathrm{c}_{\text {anode }} \mathrm{m}_{\text {anode }}
$$

The rate of depletion in reacting species content during the reaction is presented in Equation (15).

$$
\frac{\mathrm{dc}_{\text {anode }}}{\mathrm{dt}}=-\mathrm{R}_{\text {anode }}
$$


$\mathrm{z}$ is the SEI layer thickness and its temporal change is expressed in Equation (16).

$$
\frac{\mathrm{dz}}{\mathrm{dt}}=\mathrm{R}_{\text {anode }}
$$

The rate of heat evolution from the reaction can be calculated using Equation (17).

$$
\mathrm{Q}_{\text {anode }}=\Delta \mathrm{H}_{\text {anode }} \mathrm{W}_{\text {anode }} \mathrm{R}_{\text {anode }}
$$

where $R_{\text {anode }}\left(\mathrm{s}^{-1}\right)$ is the rate constant of anode-solvent reaction, $\Delta H_{\text {anode }}(\mathrm{J} / \mathrm{kg})$ is the reaction enthalpy, $\mathrm{A}_{\text {anode }}\left(\mathrm{s}^{-1}\right)$ and $\mathrm{E}_{\text {anode }}(\mathrm{J} / \mathrm{mol})$ are frequency factor and activation energy respectively, $\mathrm{R}(\mathrm{J} / \mathrm{K} \cdot \mathrm{mol})$ is the gas constant, $\mathrm{T}(\mathrm{K})$ is the battery temperature, $\mathrm{m}_{\text {anode }}$ is the reaction order, $\mathrm{W}_{\text {anode }}(\mathrm{kg})$ is the mass of carbon in anode, $\mathrm{z}$ is the thickness of SEI layer, $\mathrm{z}_{0}$ is the initial thickness of SEI layer and $\mathrm{c}_{\text {anode }}$ is the dimensionless amount of lithium intercalated within the carbon negative electrode.

\subsubsection{Electrolyte Decomposition}

As described by Spotnitz and Franklin [37], the reaction is first-order and the rate constant of this reaction can be expressed as in Equation (18).

$$
R_{\text {electrolyte }}=A_{\text {electrolyte }} \exp \left[-\frac{E_{\text {electrolyte }}}{R T}\right] c_{\text {electrolyte }} m_{\text {electrolyte }}
$$

The rate of reacting species consumption during the reaction is presented in Equation (19).

$$
\frac{\mathrm{dc}_{\text {electrolyte }}}{\mathrm{dt}}=-\mathrm{R}_{\text {electrolyte }}
$$

The rate of heat evolution from the reaction can be calculated using Equation (20).

$$
\mathrm{Q}_{\text {electrolyte }}=\Delta \mathrm{H}_{\text {electrolyte }} \mathrm{W}_{\text {electrolyte }} \mathrm{R}_{\text {electrolyte }}
$$

where $\Delta \mathrm{H}_{\text {electrolyte }}(\mathrm{J} / \mathrm{kg})$ is the reaction enthalpy, $\mathrm{A}_{\text {electrolyte }}\left(\mathrm{s}^{-1}\right)$ and $\mathrm{E}_{\text {electrolyte }}(\mathrm{J} / \mathrm{mol})$ are frequency factor and activation energy respectively, $R(\mathrm{~J} / \mathrm{K} . \mathrm{mol})$ is the gas constant, $\mathrm{T}(\mathrm{K})$ is the battery temperature, $\mathrm{m}_{\text {electrolyte }}$ is the reaction order, $\mathrm{W}_{\text {electrolyte }}(\mathrm{kg})$ is the mass of electrolyte and celectrolyte is the dimensionless electrolyte concentration.

\subsubsection{Cathode Breakdown}

Cathode breakdown is an auto-catalytic reaction [35]. The rate constant for the decomposition of positive active material reaction can be expressed as in Equation (21).

$$
\mathrm{R}_{\text {cathode }}=\mathrm{A}_{\text {cathode }} \exp \left[-\frac{\mathrm{E}_{\text {cathode }}}{\mathrm{RT}}\right] \alpha^{\mathrm{m}_{\text {cathode }}}(1-\alpha)^{\mathrm{m}_{\text {cathode }}}
$$

The extent of the reaction is changing according to the following rate, as presented in Equation (22).

$$
\frac{\mathrm{d} \alpha}{\mathrm{dt}}=\mathrm{R}_{\text {cathode }}
$$

The rate of heat evolution from the reaction can be calculated using Equation (23).

$$
\mathrm{Q}_{\text {cathode }}=\Delta \mathrm{H}_{\text {cathode }} \mathrm{W}_{\text {cathode }} \mathrm{R}_{\text {cathode }}
$$

where $\Delta \mathrm{H}_{\text {cathode }}(\mathrm{J} / \mathrm{kg})$ is the reaction enthalpy, $\mathrm{A}_{\text {cathode }}\left(\mathrm{s}^{-1}\right)$ and $\mathrm{E}_{\text {cathode }}(\mathrm{J} / \mathrm{mol})$ are frequency factor and activation energy respectively, $\mathrm{R}(\mathrm{J} / \mathrm{K} \cdot \mathrm{mol})$ is the gas constant, $\mathrm{T}(\mathrm{K})$ is the battery temperature, 
$\mathrm{m}_{\text {cathode }}$ is the reaction order, $\mathrm{W}_{\text {cathode }}(\mathrm{kg})$ is mass of the cathode and $\alpha$ is the extent of cathode decomposition reaction.

\subsection{Heat Transfer Modelling for Simulation of Thermal Runaway Propagation in a Battery Module}

For a battery module with $3 \times 3$ matrix assembly consists of nine identical cylindrical batteries, the system is regarded as a cluster of thermal nodes connected with thermal resistance networks as shown in Figure 1.

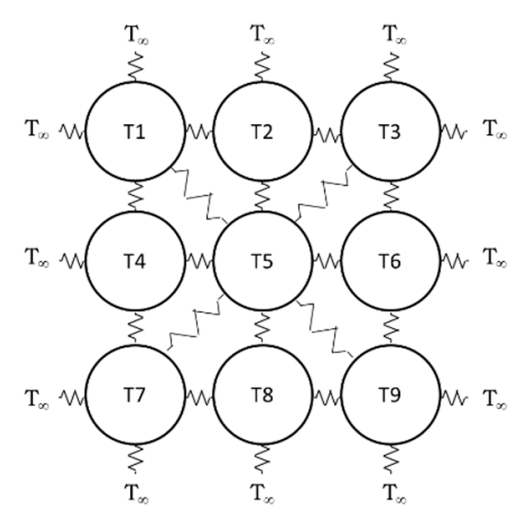

Figure 1. Thermal resistance network for heat transfer modelling.

For thermal node T5, the $\mathrm{Q}_{\text {dissipation }}$ term in Equation (3) is further expanded as in Equation (24).

$$
\mathrm{Q}_{\text {dissipation }}(\mathrm{t})=\sum_{\mathrm{i}=1}^{10} \mathrm{Q}_{\text {dissipation, } \mathrm{i}}(\mathrm{t})
$$

For thermal nodes T2, T4, T6 and T8, which are located directly adjacent to T5, the $Q_{\text {dissipation }}$ term in Equation (3) is further expanded as in Equation (25).

$$
\mathrm{Q}_{\text {dissipation }}(\mathrm{t})=\sum_{\mathrm{i}=1}^{6} \mathrm{Q}_{\text {dissipation, } \mathrm{i}}(\mathrm{t})
$$

For T1, T3, T7 and T9 thermal nodes that are perpendicular to T5, the $\mathrm{Q}_{\text {dissipation }}$ is expressed as in Equation (26).

$$
\mathrm{Q}_{\text {dissipation }}(\mathrm{t})=\sum_{\mathrm{i}=7}^{7} \mathrm{Q}_{\text {dissipation, } \mathrm{i}}(\mathrm{t})
$$

Each $\mathrm{Q}_{\text {dissipation,i }}$ term in Equations (24)-(26) can be calculated using Equation (27).

$$
\mathrm{Q}_{\text {dissipation, } \mathrm{i}}=\mathrm{A}_{\mathrm{i}} \frac{\mathrm{T}_{\mathrm{n}}-\mathrm{T}_{\mathrm{n}-1}}{\mathrm{R}_{\text {total, } \mathrm{i}}}
$$

where $A_{i}$ is the surface area for heat exchange, $R_{\text {total, } i}$ is the total thermal resistance in any direction $i$ and $T_{n}$ is temperature of thermal node $n$.

The thermal resistance network within the battery module and single cylindrical battery is illustrated in Figure 2. The description and value of each thermal resistance involved in the simulation is listed in Table 4. 
(a)

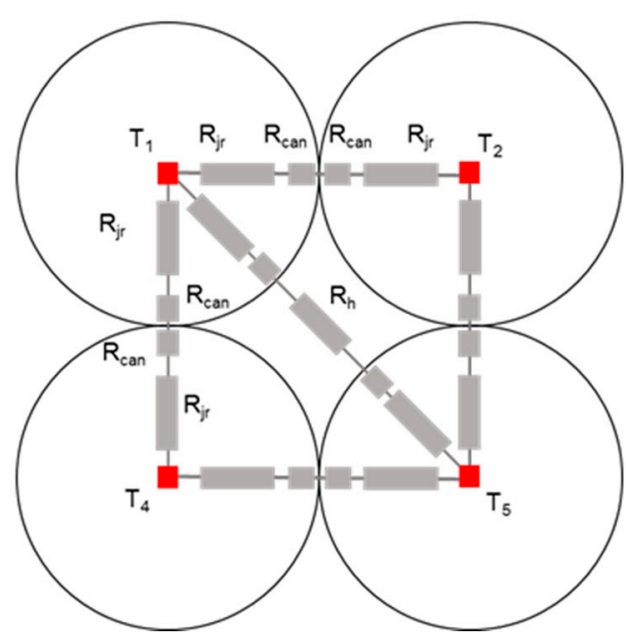

(b)

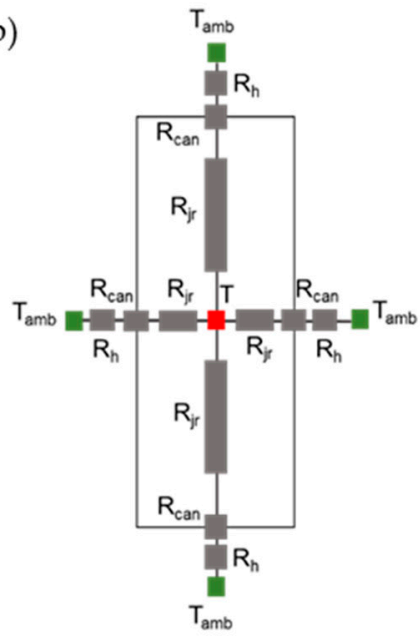

Figure 2. (a) Heat transfer resistance network within the module; (b) Heat transfer resistance network within the cylindrical cell.

Table 4. Description of all thermal resistances within the individual cell and battery module.

\begin{tabular}{|c|c|c|c|c|c|}
\hline Thermal Resistance & Description & Thickness (m) & $\begin{array}{l}\text { Thermal Conductivity } \\
\text { (W/m.K) }\end{array}$ & $\begin{array}{l}\text { Heat Transfer Coefficient } \\
\left(\mathrm{W} / \mathrm{m}^{2} . \mathrm{K}\right)\end{array}$ & Reference \\
\hline $\mathrm{R}_{\mathrm{jr}}$ & $\begin{array}{l}\text { Jellyroll (Axial) } \\
\text { (Radial) }\end{array}$ & $\begin{array}{c}0.0315 \\
0.008\end{array}$ & 3.4 & - & [30] \\
\hline $\mathrm{R}_{\text {can }}$ & $\begin{array}{l}\text { Canister } \\
\text { Convective }\end{array}$ & 0.001 & 14 & - & [30] \\
\hline $\mathrm{R}_{\mathrm{h}}$ & $\begin{array}{l}\text { heat transfer } \\
\text { resistance }\end{array}$ & - & - & 7.17 & [30] \\
\hline
\end{tabular}

\section{Results and Discussion}

\subsection{Thermal Runaway of a Single Battery Initiated by Impact-Induced Short Circuit Propagation in a Battery Module}

In a literature survey by Spotnitz and Franklin [37], it has been determined that nail, short-circuit and crush are among the common methods used to assess abuse tolerance of lithium-ion cells. In general, these three techniques share the same feature. The battery releases a large amount of heat instantaneously upon failure, which is essentially due to short-circuit. The model developed in this work, being one-dimensional, is a rough approximation of a nail and crush test. The distribution of the heat released from the nail penetration is treated to be instantaneous and uniform in the plane perpendicular to the direction of nail penetration. In a real situation, a local hotspot will form because the heat dissipation from the nail puncture spot is not rapid. Three-dimensional modelling is necessary for better consideration of thermal gradient within the battery geometry. In a work done by Lamb and Orendorff [38], the short-circuit induced by mechanical impact instigated the peak temperature of the cylindrical LIB with $\mathrm{LiCoO}_{2}$ cathode to reach between 99 to $662^{\circ} \mathrm{C}$. The battery energetic response to the mechanical impact depends on the force and orientation of the impact, and the type of indentation used in the evaluation.

Short-circuit, despite being a different mode of failure, shares some general feature with thermal abuse behavior. The simulated temperature profile for short-circuit is shown in Figure 3a. In both thermal abuse and short-circuit, two apparent stages are observed. The surge and plunge patterns of the battery temporal behavior due to short-circuit are comparable to thermal abuse. However, the temperature increment is not sharp and the temperature drop is gradual, as compared to the thermal abuse profile. 
(a)

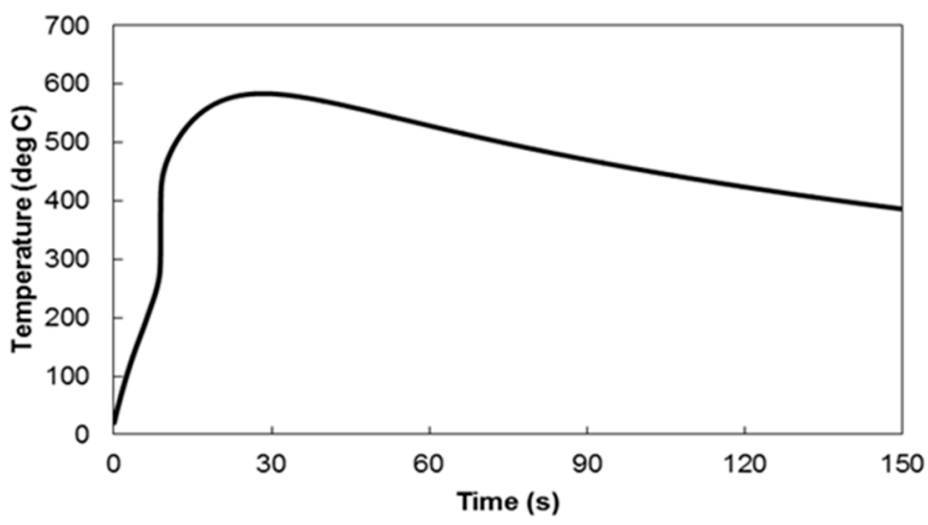

(b)

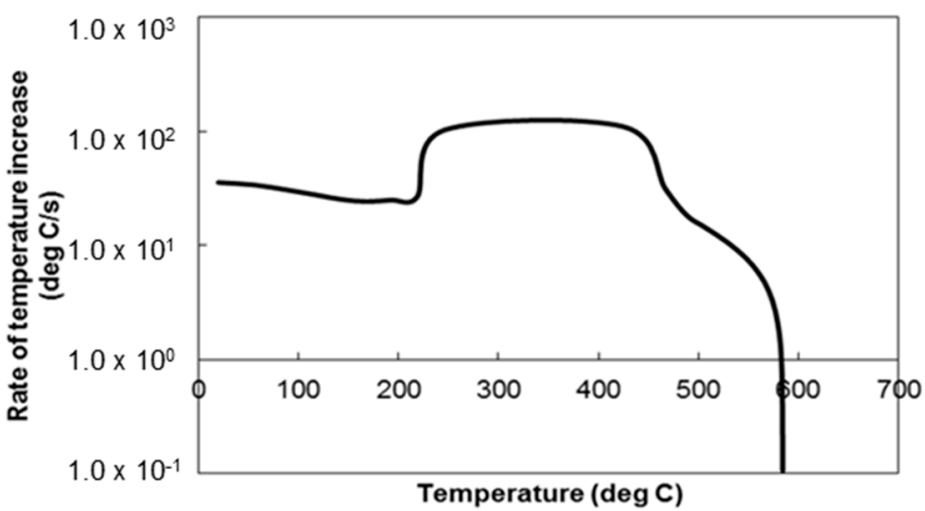

Figure 3. (a) Thermal runaway profile of a short-circuited battery; (b) rate of temperature increase profile during short-circuit.

Figure $3 b$ presents the rate of temperature increase as the battery temperature changes to decipher the heat exchange process that contributes to the battery temperature development. In comparison to thermal abuse cases, thermal runaway occurs straight away after the impact due to short-circuit. The initial temperature increment is brought by the instantaneous discharge of stored chemical energy and chemical reactions, which leads to thermal runaway. The chemical energy deposit that supposed to be converted into electrical energy during normal operation is descended as thermal energy instead via the Joule heating process.

The point of inflection between the declining curve and projectile of temperature increase rate marks the point when chemical energy becomes the dominant heat source during thermal runaway. The rate of temperature increase intensifies at higher temperature and plateaus at the intermediate temperature region. This is subsequently followed by decreasing rate temperature rise until the maximum temperature is reached.

To have a better illustration and understanding on the contribution of the chemical reactions involved and short-circuit to thermal runaway, the rate of heat generation of the respective sources is depicted in Figure 4. The heat generated in short-circuit case is contributed by a combination of both electrical and chemical energy. At the low temperature region, the amount of heat generated by chemical reactions is not significant where the initial heat generation is dominated by short-circuit. As the battery temperature increases, the exothermic reactions in the battery components proceed at a higher rate, which in turn enhance the amount of heat generated and render the dominant heat source in the intermediate temperature region. 

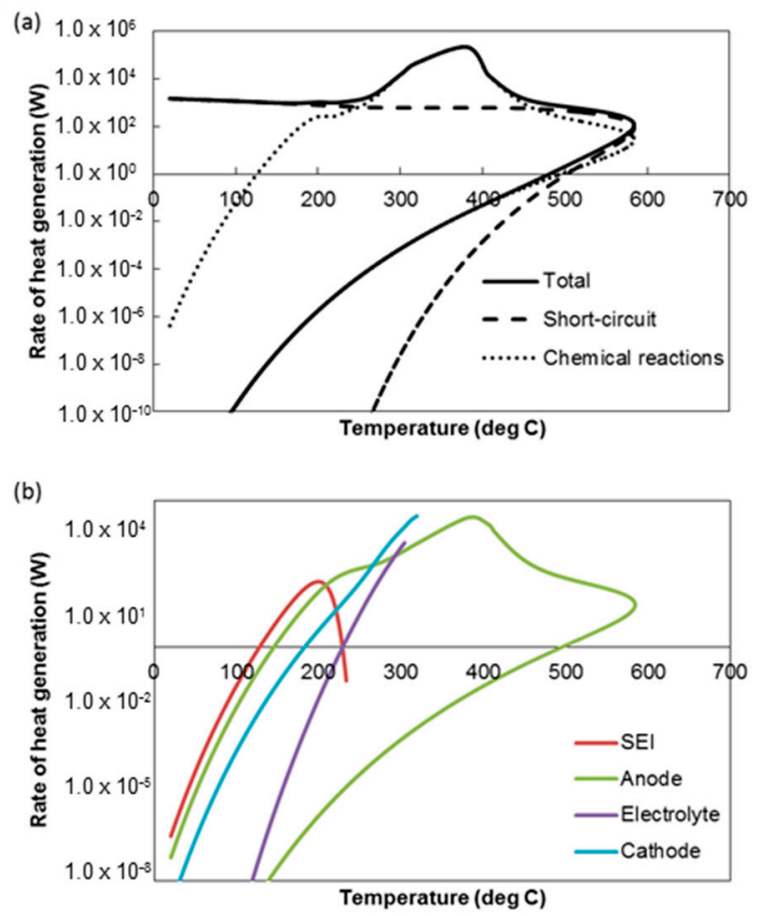

Figure 4. (a) Total rate of heat generation, which is a sum of heat released from short-circuit and chemical reactions; (b) heat release rate by individual chemical reactions.

The amount of reacting species depletes at high temperature that leads to reactions completion. The situation reduces the amount of heat generated by chemical reactions and makes short-circuit as the prevailing heat source at the high temperature region. The initial heat generation by chemical reactions is dominated by SEI breakdown. As most reactants are depleted as the battery temperature increases, the highest heat release rate at the intermediate and high temperature regions is contributed by the reaction at anode. The heat generated in short-circuit case is contributed by a combination of both electrical and chemical energy. At the low temperature region, the amount of heat generated by chemical reactions is not significant where the initial heat generation is dominated by short-circuit. As the battery temperature increases, the exothermic reactions in the battery components proceed at a higher rate, which in turn enhance the amount of heat generated and render the dominant heat source in the intermediate temperature region.

The amount of reacting species depletes at high temperature that leads to reactions completion. The situation reduces the amount of heat generated by chemical reactions and makes short-circuit as the prevailing heat source at the high temperature region. The initial heat generation by chemical reactions is dominated by SEI breakdown. As most reactants are depleted as the battery temperature increases, the highest heat release rate at the intermediate and high temperature regions is contributed by the reaction at anode. The progress of the individual reactions is presented in Figure 5. The intense amount of heat generated by short-circuit induces SEI, cathode and electrolyte reactions to completion within a short time. A sharp progress in the reactions is observed as the battery reaches peak temperature, which leads to completion of electrolyte and cathode reactions. SEI decomposition completes earlier since this reaction is the bottleneck to thermal runaway. After the highest temperature is reached, secondary SEI thickness and lithium content in anode remained plateau, indicating a halt in the reaction progress. 

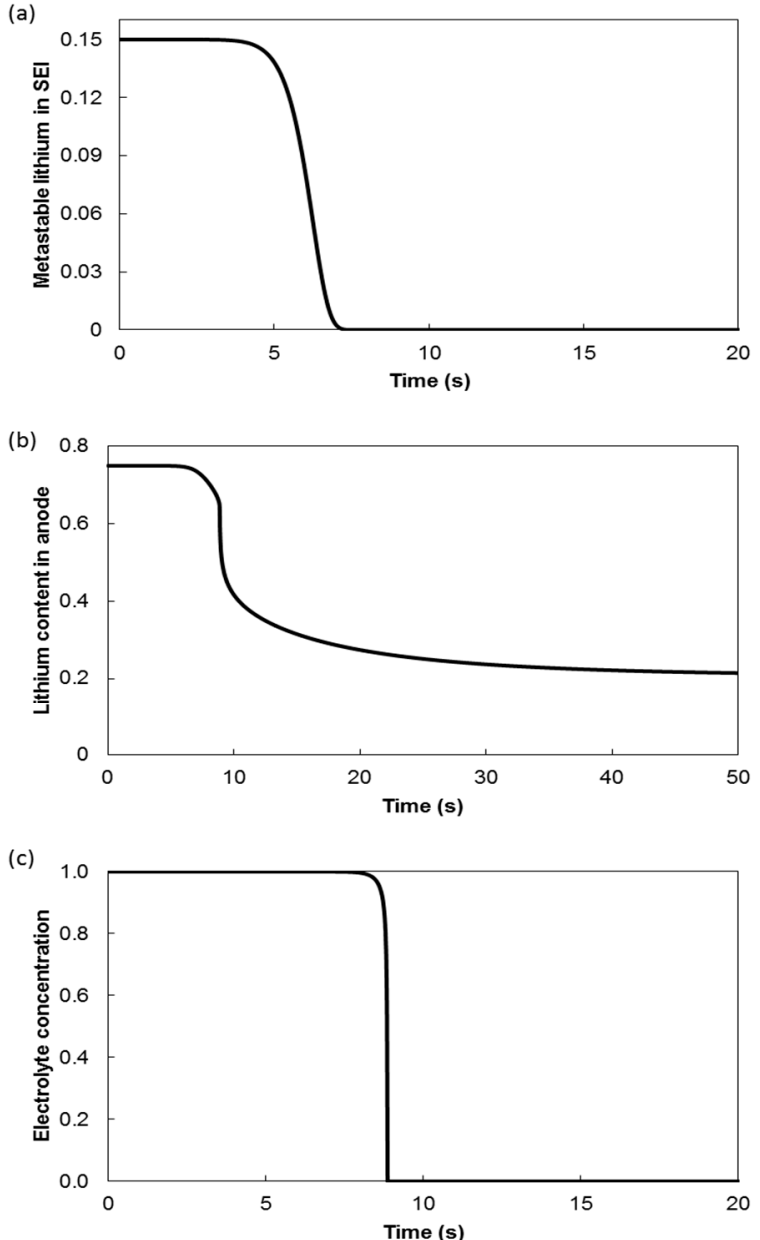

(d)
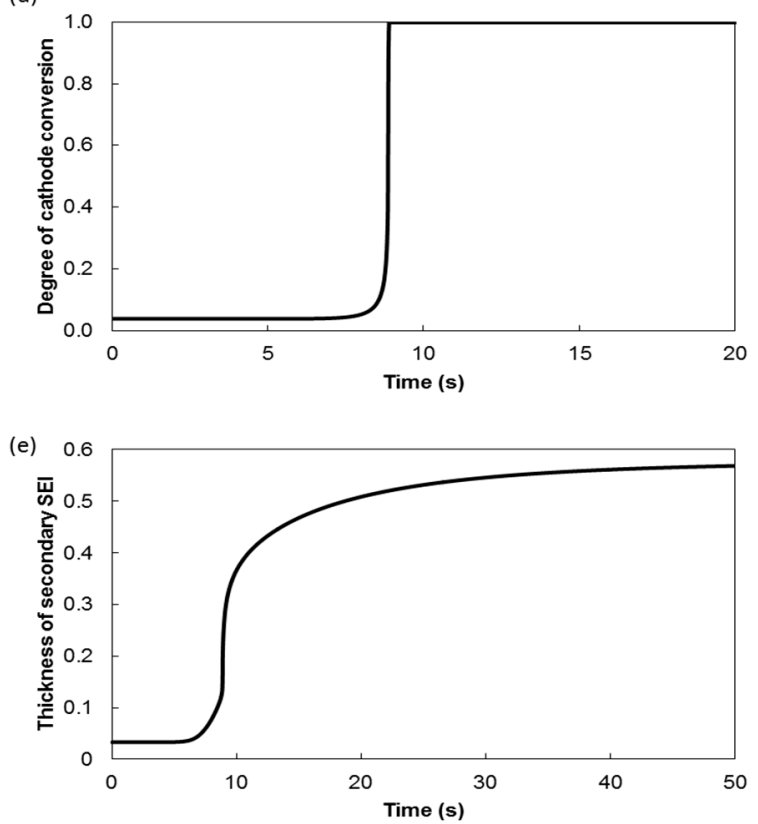

Figure 5. The progress of reaction (a) SEI; (b) anode; (c) electrolyte; (d) cathode; and (e) secondary SEI thickness, during short-circuit. 
Figure 6 presents the total rate of heat release during short-circuit. A spike is observed as the battery temperature is sufficiently high to induce the heat-activated chemical reactions in the battery components. The rate reduces dramatically after complete depletion of most reacting species. Table 5 summaries the amount of heat released by chemical reactions and the rapid discharge of electrical energy into heat during short-circuit.

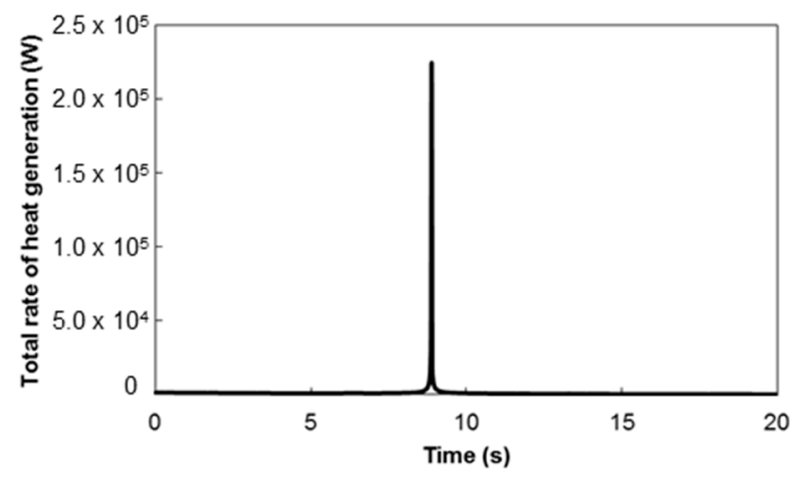

Figure 6. Total rate of heat generation in the battery during short-circuit.

Table 5. Total heat release and heat release rate during short-circuit.

\begin{tabular}{lc}
\hline Peak heat release rate $(\mathrm{W})$ & $2.25 \times 10^{5}$ \\
\hline Total heat release $(\mathrm{J})$ & $2.75 \times 10^{4}$ \\
\hline Total heat release during short-circuit $(\mathrm{J})$ & $1.5 \times 10^{4}$ \\
\hline Total heat release by SEI reaction $(\mathrm{J})$ & 247.1 \\
\hline Total heat release by anode reaction $(\mathrm{J})$ & $6.04 \times 10^{3}$ \\
\hline Total heat release by electrolyte reaction $(\mathrm{J})$ & 466.1 \\
\hline Total heat release cathode reaction $(\mathrm{J})$ & $5.76 \times 10^{3}$ \\
\hline
\end{tabular}

\subsection{Thermal Runaway Propagation in a Battery Module}

The thermal kinetic model of a single lithium-ion battery with lithium cobalt oxide chemistry was further expanded to include heat transfer modelling in order to investigate the propagation of thermal runaway in a battery module with $3 \times 3$ matrix configuration consisted of 9 identical cylindrical cells. Two thermal runaway propagation situations were developed at different positions of initial failure and the severity of the associated thermal hazard was compared. The cases were developed based on the assumption that the thermal runaway propagated from the initiated cell to the other surrounding cells by conductive and convective heat transfer. In the first case, thermal runaway was assumed to be initiated by impact-induced short-circuit in Cell 5 . The position of the failure initiation is marked in red, as illustrated in Figure 7.

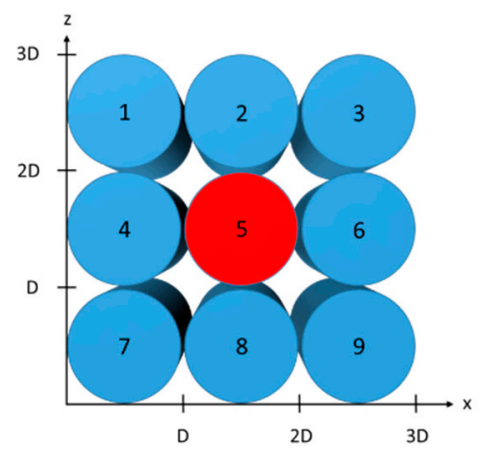

Figure 7. Thermal runaway initiation in the middle cell of the battery module. D is the battery diameter. 
The temperature development of the cells in the battery module is shown in Figure 8. Due to the symmetric nature of the $3 \times 3$ matrix configuration, all cells located at diagonals of the initiated cell, which are Cell 1, 3, 7 and 9, recorded the same temperature profile. In addition, identical temperature profiles can be observed for all cells directly adjacent to the initiated cell, which are Cell 2, 4,6 and 8 .

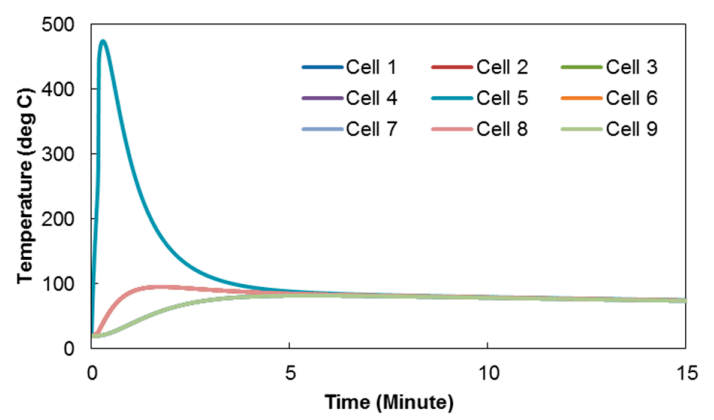

Figure 8. Temperature change of cells in the battery module.

The rapid heat release in the battery caused by short-circuit inflicts the temperature of Cell 5 to soar up to $500^{\circ} \mathrm{C}$. In general, all neighboring cells recorded a temperature rise up to $100{ }^{\circ} \mathrm{C}$. The close proximity and better surface contact of the directly adjacent cells (Cell 2, 4, 6 and 8) to the initiated cell caused the temperature to increase at a faster rate and reach a slightly higher peak compared to the cells located at the diagonals (Cell 1, 3, 7 and 9) of the battery module. All cells demonstrated an identical cooling profile after approximately $5 \mathrm{~min}$ of the failure initiation in Cell 5 . The rise of temperature in the surrounding cells could be instigated by the heat transfer process from Cell 5 , which might in turn induced the heat-activated exothermic reactions in the neighboring batteries.

In order to inspect whether the heat transfer process from the defective cell managed to activate the exothermic reactions in the neighboring cells, the progress of the reactions in all cells is shown in Figures 9 and 10. Due to the slow progress of reactions in other cells compared to Cell 5, which might be difficult to notice, the information is presented in two separate figures. The pattern of reaction progress in Cell 5 is almost identical as observed previously in thermal runaway of a single battery due to the same method of failure initiation. The reactions in cathode, electrolyte and SEI are driven to completion in a short time span by the big amount of heat generated from short-circuit. The insufficient amount of heat after the peak temperature causes the reaction in anode and the subsequent secondary SEI layer film formation to cease. In general, for all other cells in the battery module, the chemical reactions recorded a sluggish progress. A faster reaction progress can be observed for cells directly adjacent to the Cell 5 . No reaction occurred at electrolyte since the reaction is a high temperature reaction. The progress of reactions in all neighboring cells appears to be insignificant, implying the absence of thermal runaway and the temperature rise in the neighboring cells is utterly caused by heat transfer from Cell 5.

Figure 11 presents the total rate of heat release in the battery module, indicating a peak of $167.1 \mathrm{~kW}$. The heat generated in the module is sourced from a combination of both short-circuit and chemical reactions. A spike is observed as the battery temperature is sufficiently high to induce the heat-activated chemical reactions in the battery components. The rate reduces subsequently after complete depletion of most reacting species. The total amount of heat liberated in this case is $24.5 \mathrm{~kJ}$.

In the second case, thermal runaway was assumed to be initiated by impact-induced short-circuit in Cell 1. The position of the failure initiation is marked in red, as illustrated in Figure 12.

The temperature development of the cells in the battery module is shown in Figure 13. Due to the symmetric nature of the $3 \times 3$ matrix configuration, the following cells would have an identical temperature profile:

Cell 2 and Cell 4;

Cell 3 and Cell 7;

Cell 6 and Cell 8. 

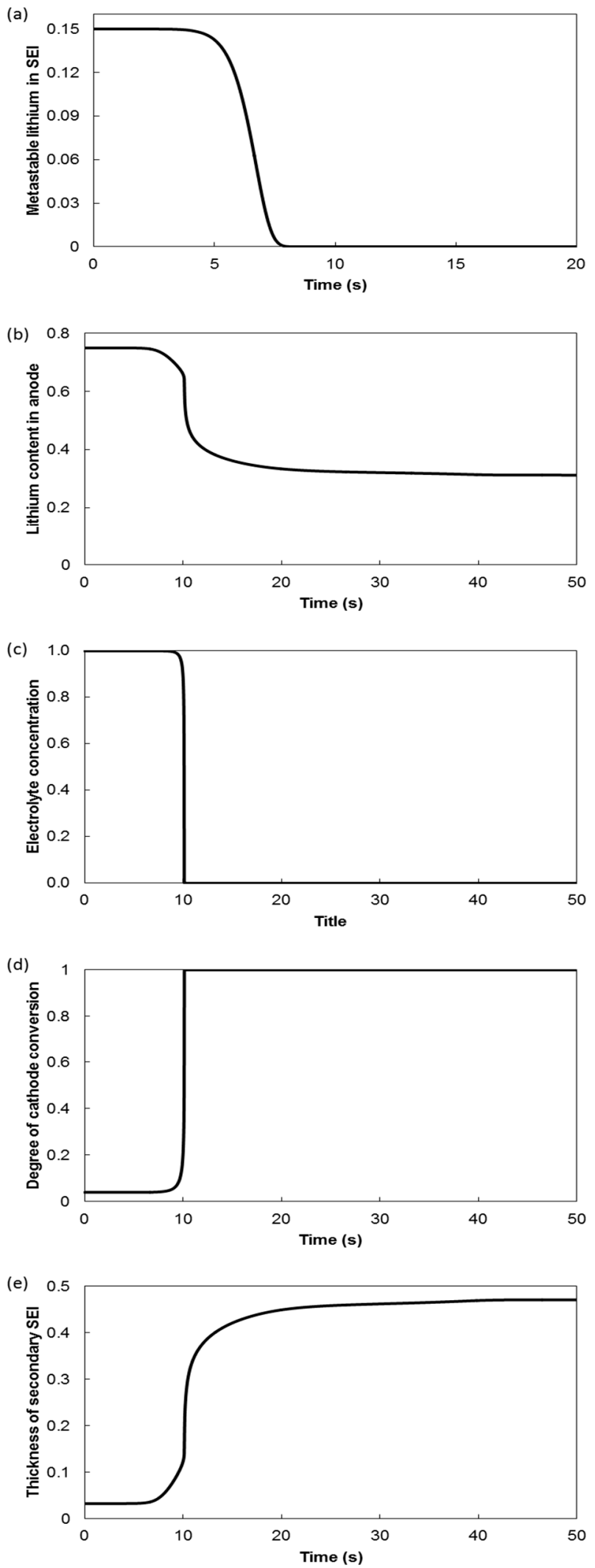

Figure 9. The progress of reaction (a) SEI; (b) anode; (c) electrolyte; (d) cathode; and (e) secondary SEI thickness, in Cell 5. 

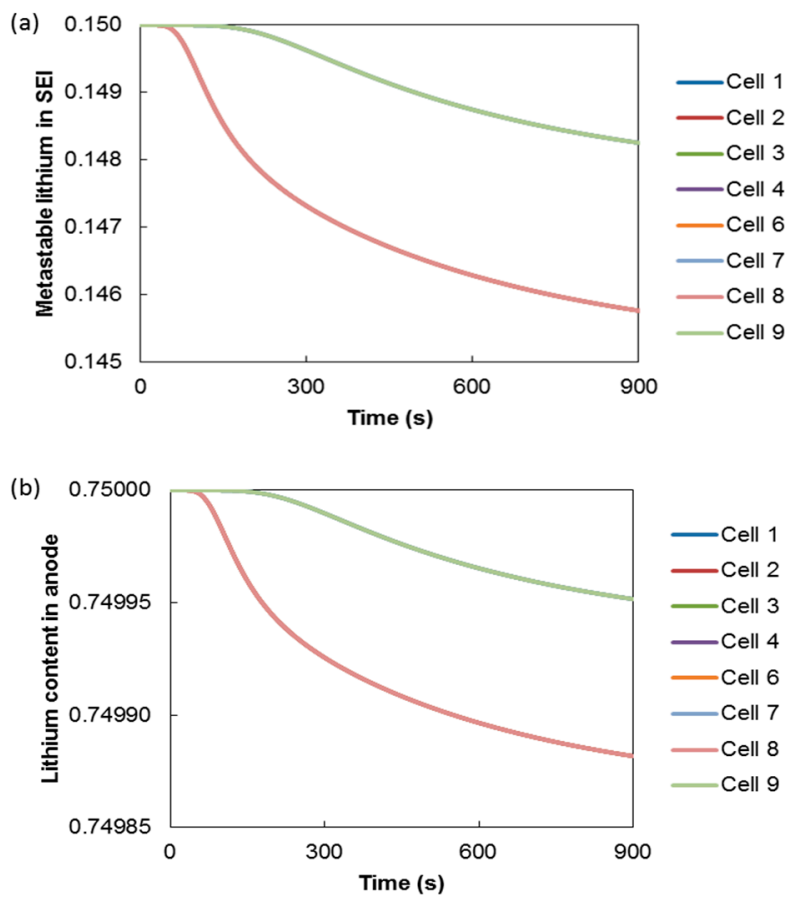

(c)
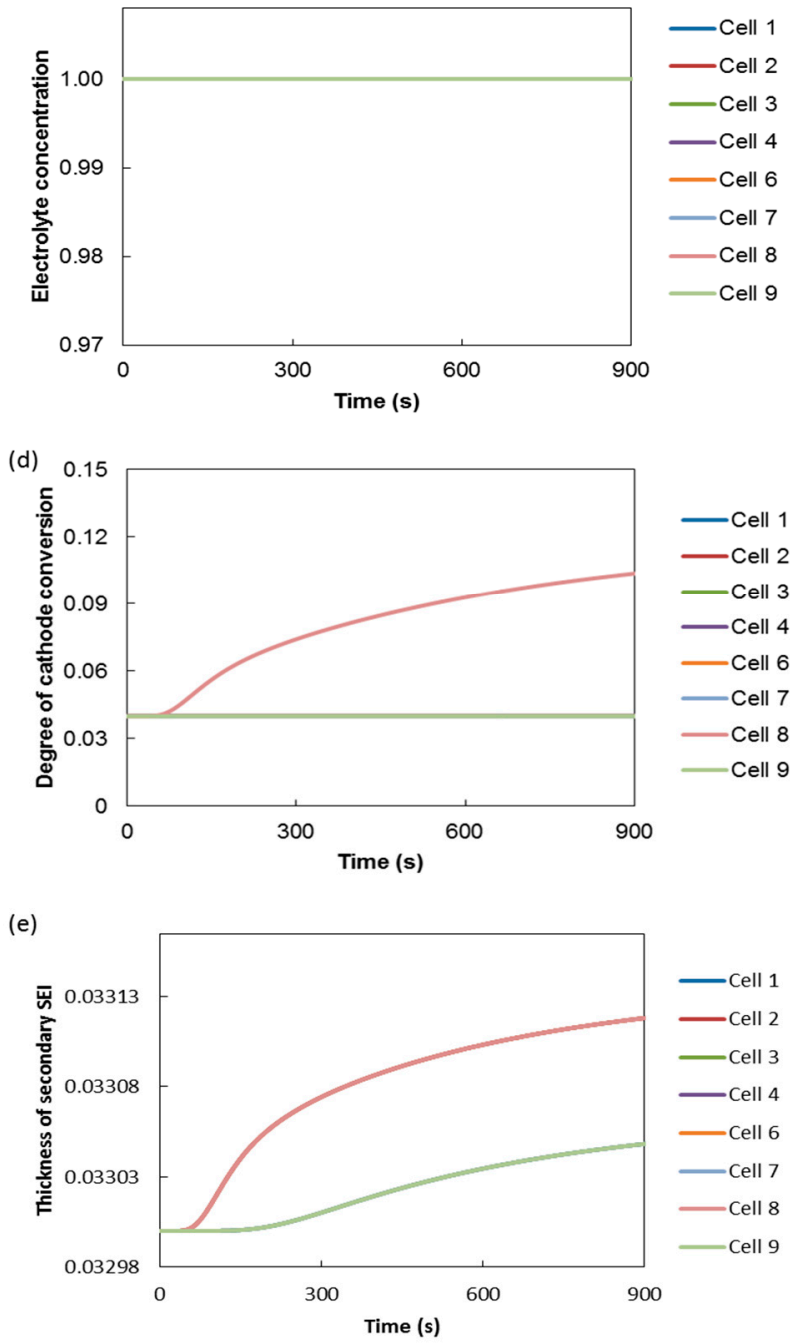

Figure 10. The progress of reaction (a) SEI (b) anode (c) electrolyte (d) cathode and (e) secondary SEI thickness, in all other cells in the battery module. 


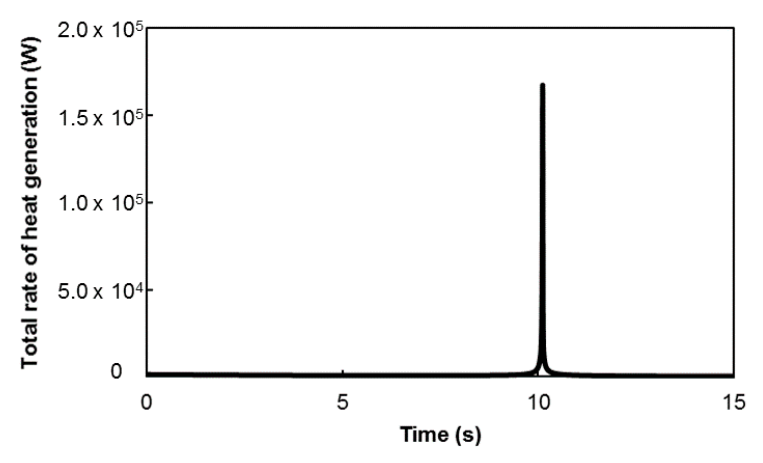

Figure 11. Rate of heat generation in the battery module.

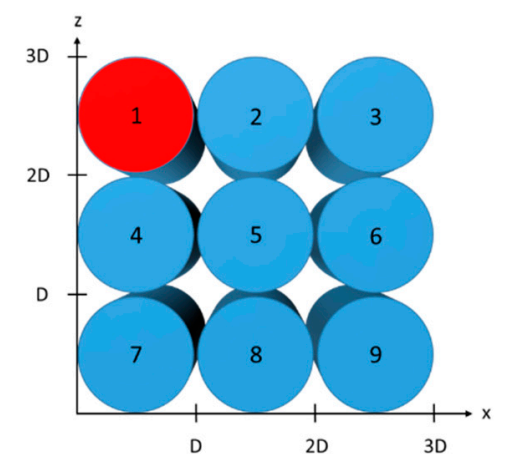

Figure 12. Thermal runaway initiation in the first cell of the battery module. $\mathrm{D}$ is the battery diameter.

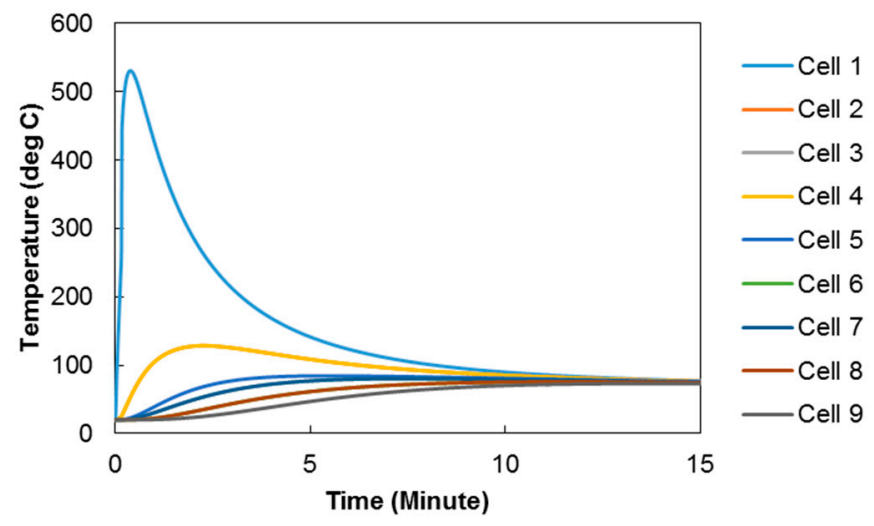

Figure 13. Temperature of cells in the battery module.

The rapid release of heat originating from conversion of electrical energy into thermal energy during short-circuit caused the temperature of Cell 1 to soar up to higher than $500{ }^{\circ} \mathrm{C}$. In general, all neighboring cells recorded a temperature rise up to $100^{\circ} \mathrm{C}$. Compared to all other neighboring cells in the module, Cell 2 and Cell 4 recorded a higher and faster temperature development due to their relative position being directly adjacent to the defective cell. The temperature of all cells converged after approximately $13 \mathrm{~min}$ and exhibited a similar cooling profile. The rise of temperature in the surrounding cells could be instigated by the heat transfer process from Cell 1, which might in turn induced the heat-activated exothermic reactions in the neighboring batteries. The progress of the reactions in all cells is shown in Figures 14 and 15. The pattern of reaction progress in Cell 1 is almost identical as observed in Cell 5 previously and for single battery thermal runaway profile due to the same method of failure initiation. The reactions in cathode, electrolyte and SEI are driven to completion in a short time span by the big amount of heat generated from short-circuit. Heat deficiency after the peak temperature retards the reaction in anode and the subsequent secondary SEI layer film formation. 

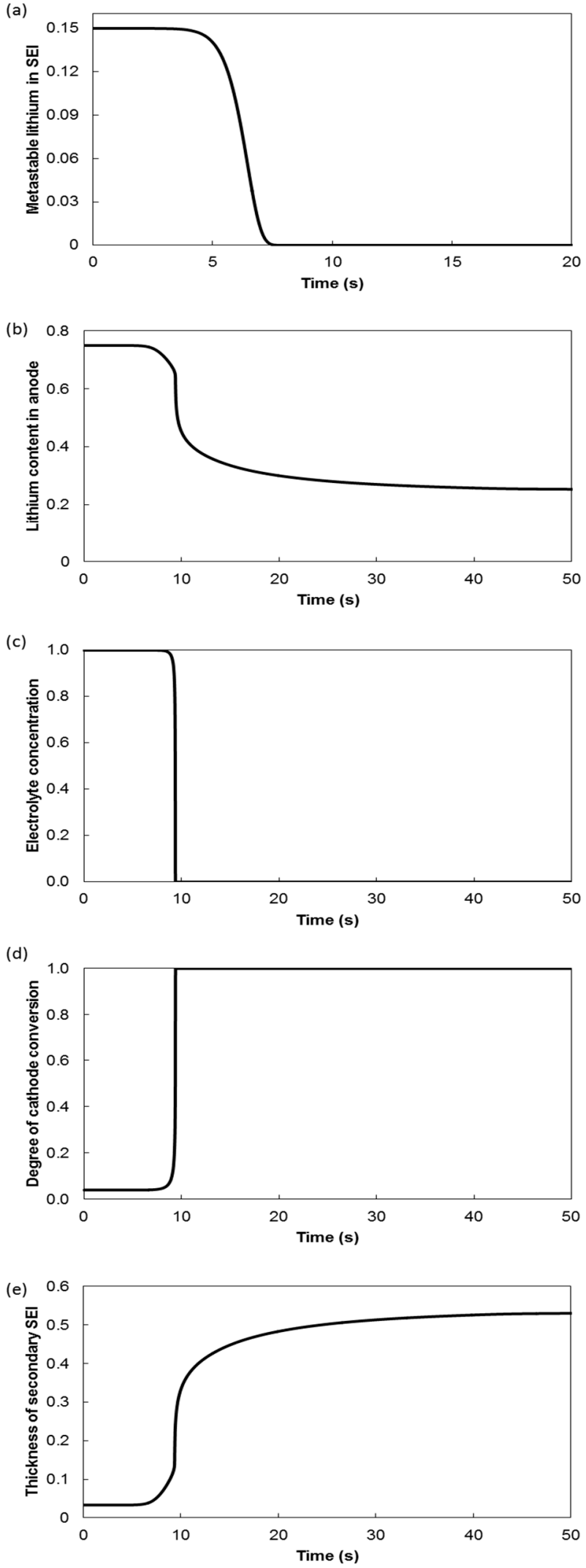

Figure 14. The progress of reaction (a) SEI (b) anode (c) electrolyte (d) cathode and (e) secondary SEI thickness, in Cell 1. 
(a)

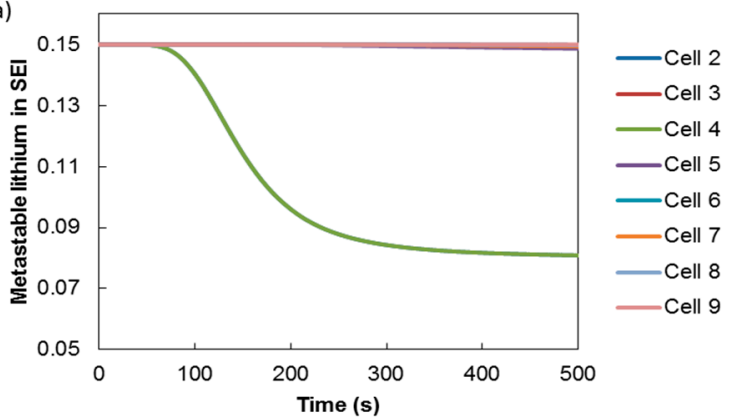

(b)
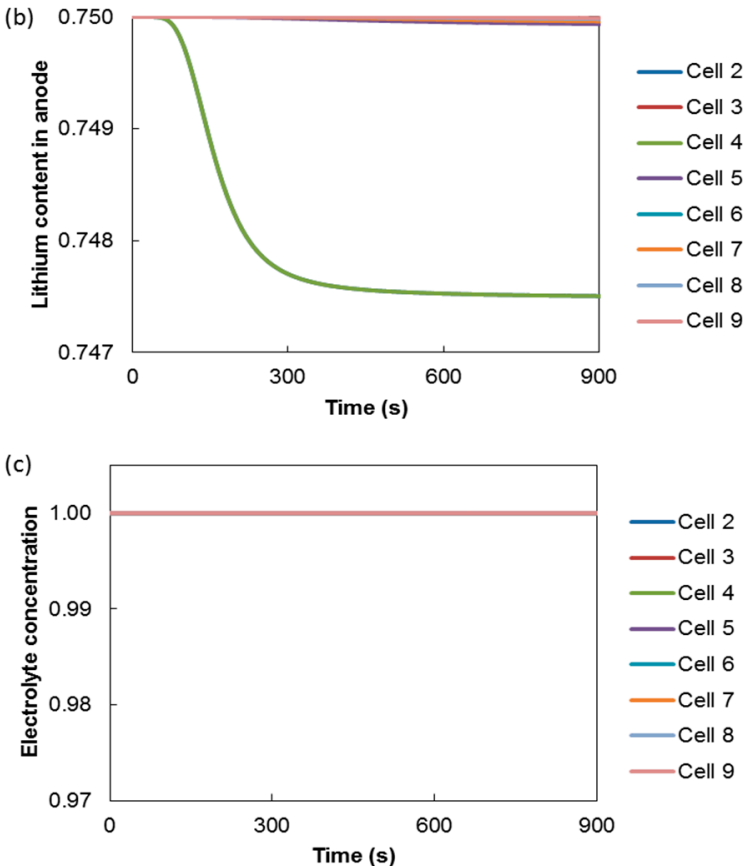

(d)
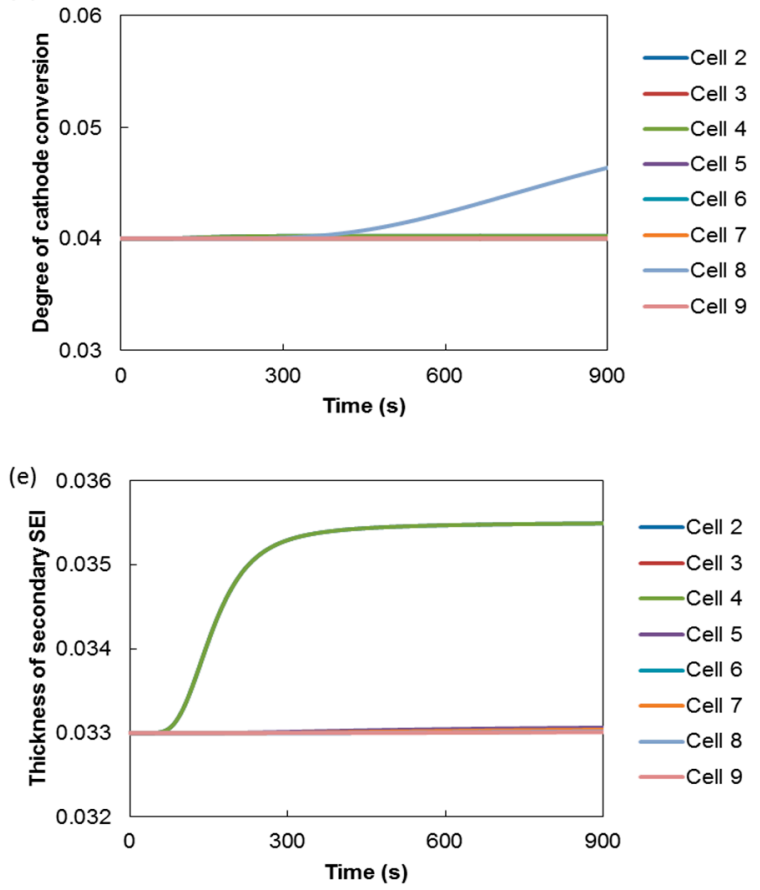

Figure 15. The progress of reaction (a) SEI (b) anode (c) electrolyte (d) cathode and (e) secondary SEI thickness, in all other cells in the battery module. 
In general, for all other cells in the battery module, the chemical reactions recorded a sluggish progress. A faster reaction progress can be observed for cells directly adjacent to the Cell 1 . No reaction occurred at electrolyte since the reaction is a high temperature reaction. The heat transferred from the defective cell to the surrounding cells was not sufficient to induce thermal runaway propagation in the entire module. Figure 16 presents the total rate of heat release in the battery module, with a peak of $211.9 \mathrm{~kW}$. Heat amounting to $25.8 \mathrm{~kJ}$ is released in the process.

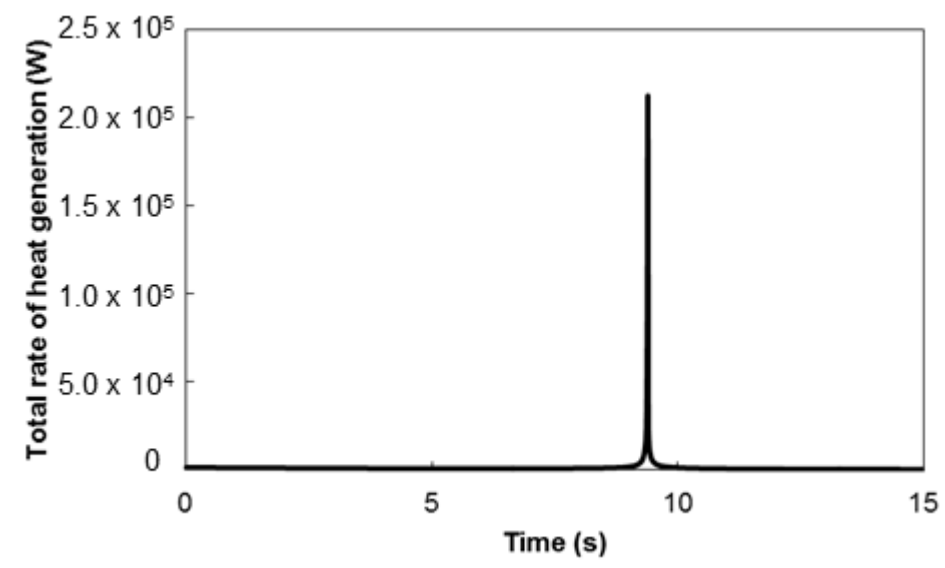

Figure 16. Total rate of heat generation in the battery module.

The simulated thermal behavior of the battery module is qualitatively in good agreement with the simulation work of Kim and Pesaran in [39] and experimental work of Wilke et al. in [40]. In both cases, thermal runaway propagation was not observed. Limited contact surface area retards the heat transfer process and deters the propagation of thermal runaway to the neighboring cells. The small size of the cylindrical cells entails high surface area-to-volume ratio that promotes heat dissipation to the surrounding and prevents heat accumulation within the battery. A battery module consists of 9 cylindrical cells with $3 \times 3$ matrix configuration is a conductive thermal network. As a result, the initiation of failure in the center of the module (Cell 5) results in less severe thermal runaway. The heat is conducted away from the defective cell through the thermal network and is being distributed evenly within the module. This situation in turn reduces the maximum rate of heat release and the subsequent peak temperature with delayed thermal runaway time. In case where the failure was initiated in the edge (Cell 1), the defective cell recorded a higher and earlier peak rate of heat release and the ensuing temperature. Heat transfer by convection from the defective cell to the surrounding is not vigorous compared to conduction, which consequently slows down the heat dissipation process.

\section{Conclusions}

A numerical model has been developed to predict thermal runaway propagation in a battery module consists of nine identical cylindrical lithium-ion batteries. The task involves establishing thermal runaway model for a single battery from thermal decomposition of reactive components in a single battery, and further expanded to include heat transfer modelling. The modelling of thermal decomposition kinetics of battery components enables comprehensive understanding of relative contribution of the battery components towards thermal runaway. Impact-induced short-circuit inflicts an immediate failure which in turn results in surge of the battery temperature. A high peak heat release rate is observed during short-circuit due to the combination of electrical and chemical energy that contributes to total thermal hazard. For a battery module consists of 9 cylindrical 18,650 cells, thermal runaway does not propagate. The small contact surface for the cylindrical geometry deters the heat transfer from the defective cell to the neighboring cells. The model developed in this work provides a baseline for further study of thermal runaway propagation in a battery module with multiple initial defects. 
Author Contributions: Conceptualization, M.S.M.S. and M.Z.M.T.; methodology, M.S.M.S. and M.Z.M.T.; formal analysis, M.S.M.S.; investigation, M.S.M.S.; writing—original draft preparation, M.S.M.S.; writing-review and editing, M.S.M.S. and M.Z.M.T.; funding acquisition, M.S.M.S.

Funding: This research was funded by Universiti Putra Malaysia and Ministry of Education Malaysia.

Conflicts of Interest: The authors declare no conflict of interest.

\section{References}

1. Buss, J. Automakers Need A Global Timetable For Phasing Out Internal-Combustion Engines. 2018. Available online: https://www.forbes.com/sites/oliverwyman/2018/03/27/automakers-need-a-global-timetable-forphasing-out-internal-combustion-engines/\#3808e5b223c3 (accessed on 19 June 2018).

2. Randall, M. Tesla Flips the Switch on the Gigafactory. 2017. Available online: https: //www.bloomberg.com/news/articles/2017-01-04/tesla-flips-the-switch-on-the-gigafactory?cmpid= socialflow-facebook-business\&utm_content=business\&utm_campaign=socialflow-organic\&utm_source= facebook\&utm_medium=social (accessed on 14 January 2017).

3. Lu, L.; Han, X.; Li, J.; Hua, J.; Ouyang, M. A review on the key issues for lithium-ion battery management in electric vehicles. J. Power Sources 2013, 226, 272-288. [CrossRef]

4. Behrmann, E.; Farchy, J.; Dodge, S. Hype Meets Reality as Electric Car Dreams Run Into Metal Crunch. 2018. Available online: https://www.bloomberg.com/graphics/2018-cobalt-batteries/ (accessed on 19 June 2018).

5. Doughty, D.H. Battery Safety and Abuse Tolerance. In Handbook of Battery Materials; Daniel, C., Besenhard, J.O., Eds.; Wiley-VCH Verlag GmbH \& Co. KGaA: Weinheim, Germany, 2011; pp. 905-938.

6. Torabi, F.; Esfahanian, V. Study of Thermal-Runaway in Batteries I. Theoretical Study and Formulation. J. Electrochem. Soc. 2011, 158, A850-A858. [CrossRef]

7. Kim, G.H.; Pesaran, A.; Smith, K. Thermal Abuse Modeling of Li-Ion Cells and Propagation in Modules. In Proceedings of the 4th International Symposium on Large Lithium Ion Battery Technology and Application, Tampa, FL, USA, 13-16 May 2008.

8. Golubkov, A.W.; Fuchs, D.; Wagner, J.; Wiltsche, H.; Stangl, C.; Fauler, G.; Voitic, G.; Thaler, A.; Hacker, V. Thermal-runaway experiments on consumer Li-ion batteries with metal-oxide and olivin-type cathodes. RSC Adv. 2014, 4, 3633-3642. [CrossRef]

9. Venugopal, G. Characterization of thermal cut-off mechanisms in prismatic lithium-ion batteries. J. Power Sources 2001, 101, 231-237. [CrossRef]

10. Liu, X.; Stoliarov, S.I.; Denlinger, M.; Masias, A.; Snyder, K. Comprehensive calorimetry of the thermally-induced failure of a lithium ion battery. J. Power Sources 2015, 280, 516-525. [CrossRef]

11. Larsson, F.; Mellander, B.E. Abuse by External Heating, Overcharge and Short Circuiting of Commercial Lithium-Ion Battery Cells. J. Electrochem. Soc. 2014, 161, A1611-A1617. [CrossRef]

12. Lisbona, D.; Snee, T. A review of hazards associated with primary lithium and lithium-ion batteries. Process Saf. Environ. Prot. 2011, 89, 434-442. [CrossRef]

13. Kim, G.H.; Pesaran, A.; Spotnitz, R. A three-dimensional thermal abuse model for lithium-ion cells. J. Power Sources 2007, 170, 476-489. [CrossRef]

14. Zhang, Z.; Fouchard, D.; Rea, J.R. Differential scanning calorimetry material studies: Implications for the safety of lithium-ion cells. J. Power Sources 1998, 70, 16-20. [CrossRef]

15. Richard, M.N.; Dahn, J.R. Accelerating Rate Calorimetry Study on the Thermal Stability of Lithium Intercalated Graphite in Electrolyte. J. Electrochem. Soc. 1999, 146, 2068-2077. [CrossRef]

16. Biensan, P.; Simon, B.; Pérès, J.P.; de Guibert, A.; Broussely, M.; Bodet, J.M.; Perton, F. On safety of lithium-ion cells. J. Power Sources 1999, 81-82, 906-912. [CrossRef]

17. Roth, E.P.; Nagasubramanian, G. Thermal Stability of Electrodes in Lithium-Ion Cells; Sandia National Laboratories: Albuquerque, NM, USA, 2000.

18. Wang, Q.; Sun, J.; Yao, X.; Chen, C. Thermal stability of LiPF6/EC+DEC electrolyte with charged electrodes for lithium ion batteries. Thermochim. Acta 2005, 437, 12-16. [CrossRef] 
19. Wang, Q.S.; Sun, J.H.; Chen, C.H.; Zhou, X.M. Thermal properties and kinetics study of charged $\mathrm{LiCoO}_{2}$ by TG and C80 methods. J. Therm. Anal. Calorim. 2008, 92, 563-566. [CrossRef]

20. MacNeil, D.D.; Dahn, J.R. Test of Reaction Kinetics Using Both Differential Scanning and Accelerating Rate Calorimetries As Applied to the Reaction of $\mathrm{Li}_{x} \mathrm{CoO}_{2}$ in Non-aqueous Electrolyte. J. Phys. Chem. A 2001, 105, 4430-4439. [CrossRef]

21. Mendoza-Hernandez, O.S.; Ishikawa, H.; Nishikawa, Y.; Maruyama, Y.; Umeda, M. Cathode material comparison of thermal runaway behavior of Li-ion cells at different state of charges including over charge. J. Power Sources 2015, 280, 499-504. [CrossRef]

22. Feng, X.; Fang, M.; He, X.; Ouyang, M.; Lu, L.; Wang, H.; Zhang, M. Thermal runaway features of large format prismatic lithium ion battery using extended volume accelerating rate calorimetry. J. Power Sources 2014, 255, 294-301. [CrossRef]

23. Doughty, D.H.; Pesaran, A.A. Vehicle Battery Safety Roadmap Guidance; National Renewable Energy Laboratory: Golden, CO, USA, 2012.

24. Chen, W.C.; Wang, Y.W.; Shu, C.M. Adiabatic calorimetry test of the reaction kinetics and self-heating model for 18650 Li-ion cells in various states of charge. J. Power Sources 2016, 318, 200-209. [CrossRef]

25. Jhu, C.Y.; Wang, Y.W.; Wen, C.Y.; Chiang, C.C.; Shu, C.M. Self-reactive rating of thermal runaway hazards on 18650 lithium-ion batteries. J. Therm. Anal. Calorim. 2011, 106, 159-163. [CrossRef]

26. Jhu, C.Y.; Wang, Y.W.; Shu, C.M.; Chang, J.C.; Wu, H.C. Thermal explosion hazards on 18650 lithium ion batteries with a VSP2 adiabatic calorimeter. J. Hazard. Mater. 2011, 192, 99-107. [CrossRef]

27. Jhu, C.Y.; Wang, Y.W.; Wen, C.Y.; Shu, C.M. Thermal runaway potential of $\mathrm{LiCoO}_{2}$ and $\mathrm{Li}\left(\mathrm{Ni}_{1 / 3} \mathrm{Co}_{1 / 3} \mathrm{Mn}_{1 / 3}\right) \mathrm{O}_{2}$ batteries determined with adiabatic calorimetry methodology. Appl. Energy 2012, 100, 127-131. [CrossRef]

28. Wen, C.Y.; Jhu, C.Y.; Wang, Y.W.; Chiang, C.C.; Shu, C.M. Thermal runaway features of 18650 lithium-ion batteries for $\mathrm{LiFePO}_{4}$ cathode material by DSC and VSP . J. Therm. Anal. Calorim. 2012, 109, 1297-1302. [CrossRef]

29. Lu, T.Y.; Chiang, C.C.; Wu, S.H.; Chen, K.C.; Lin, S.J.; Wen, C.Y.; Shu, C.M. Thermal hazard evaluations of 18650 lithium-ion batteries by an adiabatic calorimeter. J. Therm. Anal. Calorim. 2013, 114, 1083-1088. [CrossRef]

30. Hatchard, T.D.; MacNeil, D.D.; Basu, A.; Dahn, J.R. Thermal Model of Cylindrical and Prismatic Lithium-Ion Cells. J. Electrochem. Soc. 2001, 148, A755-A761. [CrossRef]

31. Lopez, C.F.; Jeevarajan, J.A.; Mukherjee, P.P. Characterization of Lithium-Ion Battery Thermal Abuse Behavior Using Experimental and Computational Analysis. J. Electrochem. Soc. 2015, 162, A2163-A2173. [CrossRef]

32. Lee, C.H.; Bae, S.J.; Jang, M. A study on effect of lithium ion battery design variables upon features of thermal-runaway using mathematical model and simulation. J. Power Sources 2015, 293, 498-510. [CrossRef]

33. Richard, M.N.; Dahn, J.R. Predicting electrical and thermal abuse behaviours of practical lithium-ion cells from accelerating rate calorimeter studies on small samples in electrolyte. J. Power Sources 1999, 79, 135-142. [CrossRef]

34. Richard, M.N.; Dahn, J.R. Accelerating Rate Calorimetry Study on the Thermal Stability of Lithium Intercalated Graphite in Electrolyte. II. Modeling the Results and Predicting Differential Scanning Calorimeter Curves. J. Electrochem. Soc. 1999, 146, 2078-2084. [CrossRef]

35. MacNeil, D.D.; Christensen, L.; Landucci, J.; Paulsen, J.M.; Dahn, J.R. An Autocatalytic Mechanism for the Reaction of $\mathrm{Li}_{x} \mathrm{CoO}_{2}$ in Electrolyte at Elevated Temperature. J. Electrochem. Soc. 2000, 147, 970-979. [CrossRef]

36. Feng, X.; He, X.; Ouyang, M.; Lu, L.; Wu, P.; Kulp, C.; Prasser, S. Thermal runaway propagation model for designing a safer battery pack with $25 \mathrm{Ah} \mathrm{LiNi}_{x} \mathrm{Co}_{y} \mathrm{Mn}_{z} \mathrm{O}_{2}$ large format lithium ion battery. Appl. Energy 2015, 154, 74-91. [CrossRef]

37. Spotnitz, R.; Franklin, J. Abuse behavior of high-power, lithium-ion cells. J. Power Sources 2003, 113, 81-100. [CrossRef]

38. Lamb, J.; Orendorff, C.J. Evaluation of mechanical abuse techniques in lithium ion batteries. J. Power Sources 2014, 247, 189-196. [CrossRef] 
39. Kim, G.H.; Pesaran, A. Analysis of Heat Dissipation in Li-Ion Cells \& Modules for Modeling of Thermal Runaway. In Proceedings of the 3rd International Symposium on Large Lithium Ion Battery Technology and Application, Long Beach, CA, USA, 15 May 2007.

40. Wilke, S.; Schweitzer, B.; Khateeb, S.; Al-Hallaj, S. Preventing thermal runaway propagation in lithium ion battery packs using a phase change composite material: An experimental study. J. Power Sources 2017, 340,51-59. [CrossRef]

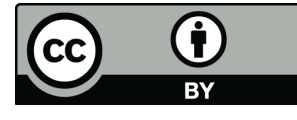

(C) 2019 by the authors. Licensee MDPI, Basel, Switzerland. This article is an open access article distributed under the terms and conditions of the Creative Commons Attribution (CC BY) license (http://creativecommons.org/licenses/by/4.0/). 